\title{
MAPEAMENTO DA FRAGILIDADE AMBIENTAL DA BACIA DO RIBEIRÃO DO ESCALVADO - MG
}

\author{
Aline da Silva Xavier Marcos \\ Felipe Gomes Rubira² \\ Rodrigo José Pisani
}

RESUMO: Fatores genéticos do ambiente físico-natural podem apresentar características frágeis, suscetíveis a ocorrência de processos de degradação. Tal fato, associado à ocupação humana desordenada, agrava a fragilidade desses ambientes naturais. A partir dessas premissas, esta pesquisa objetiva classificar, mapear e analisar a fragilidade ambiental da bacia do ribeirão do Escalvado (MG) a partir da proposta metodológica de Ross (2012). Para tanto, foram realizados mapeamentos de variáveis relacionadas à declividade, drenagem, solos, geologia, dissecação do relevo e uso da terra. Estes parâmetros foram sobrepostos por meio de análise ponderada associada ao método de processo hierárquico analítico (AHP). Os resultados da sobreposição entre as variáveis naturais resultaram na distinção de classes de fragilidade potencial média (86,49\%), forte $(11,38 \%)$ e baixa $(2,13 \%)$. Com relação à fragilidade emergente, a partir do cruzamento com as classes de uso da terra, obteve-se resultados que evidenciaram predomínio de classe de fragilidade emergente forte $(64,85 \%)$, fraca $(21,47 \%)$, muito forte $(8,11 \%)$, média $(4,69 \%)$ e muito fraca $(0,88 \%)$. Concluiu-se que os ambientes frágeis da bacia se apresentaram condizentes tanto com sua historicidade relacionada à ocupação da sociedade, quanto à evolução geocronológica do sistema natural.

PALAVRAS-CHAVE: Sobreposição ponderada; Fragilidade potencial; Fragilidade emergente; Bacia hidrográfica; Mapeamento;

\section{ENVIRONMENTAL FRAGILITY MAPPING IN THE RIBEIRÃO DO ESCALVADO BASIN - MG}

\begin{abstract}
Genetic factors of the physical-natural environment can present fragile characteristics, susceptible to the occurrence of degradation processes. This fact, associated with disordered human occupation, aggravates the fragility of these natural environments. Based on these premises, this research aims to classify, map and analyze the environmental fragility of the Ribeirão do Escalvado (MG) basin, based on the methodological proposal of Ross (2012). For this purpose, variables related to slope, drainage, soils, geology, relief dissection and land use were mapped. These parameters 1 Discente do curso de Geografia (bacharelado) na Universidade Federal de Alfenas (UNIFAL-MG) E-mail: aline.marcos@sou.unifal-mg.edu.br

2 Docente adjunto na Universidade Federal de Alfenas (UNIFAL-MG) - E-mail: felipe.rubira@unifalmg.edu.br

${ }^{3}$ Docente adjunto na Universidade Federal de Alfenas (UNIFAL-MG) - E-mail: rodrigo.pisani@unifalmg.edu.br
\end{abstract}


were overlaid by weighted analysis associated with the hierarchical analytical process (AHP) method. The results of the overlap between the natural variables resulted in the distinction between medium (86,49\%), strong $(11,38 \%)$ and low $(2,13 \%)$ classes of potential fragiltiy. Regarding emerging fragility, from the crossover with land use classes, results were obtained that showed a predominance of strong $(64,85 \%)$, weak $(21,47 \%)$, very strong $(8,11 \%)$, medium $(4,69 \%)$ and very weak $(0,88 \%)$. It was concluded that the fragile environments of the basin were consistent both with its historicity related to the occupation of society, as well as the geochronological evolution of the natural system.

KEYWORDS: Weighted overlap; Potential fragility; Emerging fragility; Hydrographic basin; Mapping.

\section{MAPEO DE LA FRAGILIDAD AMBIENTAL EN LA CUENCA DEL RIBEIRÃO DO ESCALVADO - MG}

RESUMEN: Los factores genéticos del medio físico-natural pueden presentar características frágiles, susceptibles a la ocurrencia de procesos de degradación. Este hecho, asociado a la ocupación humana desordenada, agrava la fragilidad de estos entornos naturales. Con base en estas premisas, esta investigación tiene como objetivo clasificar, mapear y analizar la fragilidad ambiental de la cuenca de Ribeirão do Escalvado (MG), a partir de la propuesta metodológica de Ross (2012). Por lo tanto, se realizaron mapeos de variables relacionadas con pendiente, drenaje, suelos, geología, relieve y uso del suelo. Estos parámetros se superpusieron mediante un análisis ponderado asociado con el método del proceso analítico jerárquico (AHP). Los resultados de la superposición entre las variables naturales dieron como resultado la distinción entre clases de fragilidad potencial media $(86,49 \%)$, fuerte $(11,38 \%)$ y baja $(2,13 \%)$. En cuanto a la fragilidad emergente, del cruce con clases de uso del suelo se obtuvieron resultados que mostraron un predominio de fuerte $(64,85 \%)$, débil $(21,47 \%)$, muy fuerte $(8,11 \%)$, medio $(4,69 \%)$ y muy débil $(0,88 \%)$. Se concluyó que los frágiles ambientes de la cuenca eran consistentes tanto con su historicidad relacionada con la ocupación de la sociedad, como con la evolución geocronológica del sistema natural.

PALABRAS-CLAVE: Superposición ponderada; Fragilidad potencial; Fragilidad emergente; Cuenca hidrográfica; Cartografía;

\section{INTRODUÇÃO}

Do ponto de vista histórico a estruturação da sociedade no território brasileiro ocorreu de forma desordenada e, consequentemente, inúmeros impactos negativos afetaram o meio ambiente. Comumente, observa-se que a 
conservação dos recursos naturais fica delegada em segundo plano frente aos interesses econômicos, ocasionando conturbações nos sistemas ambientais. Neste ínterim, a análise quantitativa e qualitativa das características físicasambientais precisa do vínculo interdisciplinar, portanto, tratar os problemas de forma isolada é negar relações sistêmicas que envolvem o espaço.

Nesta perspectiva, Felippe et al. (2016) contextualizam a historicidade conturbada relativa ao avanço populacional no território brasileiro. Para os autores, as ocupações humanas sempre priorizaram a busca por espaços com disponibilidade hídrica para a população. Consequentemente, bacias hidrográficas sofreram atos críticos de degradação ambiental no decorrer do tempo, seja por despejo de resíduos sem tratamento, desmatamento das matas nativas, implementação de atividades agropecuárias, ocupação ilegal, entre outros fatores.

Nesta discussão, Lemos Filho et al. (2017) apontam que a busca e extração dos recursos naturais se encontram em uma linha crescente e, em virtude disso, observa-se atualmente a intensificação e agravamento dos processos de degradação ambiental em bacias hidrográficas. Tamanha procura, entretanto, com o mal gerenciamento das reservas dos mananciais, acaba acarretando déficit hídrico, traduzido em crises e conflitos pelo uso da água.

Fundamentada nestas concepções teóricas, esta pesquisa objetiva classificar, mapear e analisar a fragilidade ambiental da bacia hidrográfica do Ribeirão do Escalvado-MG a partir da proposta metodológica de Ross (2012). Para tanto utilizou-se da sistematização e correlação de variáveis vinculadas à declividade das vertentes, substrato geológico, grau de dissecação do relevo, classes de solos e uso da terra com apoio de ferramentas de geoprocessamento em ambiente Geographic Information System (GIS) (álgebra de mapas e sobreposição ponderada). 
Com base nesta problemática esta pesquisa se justifica, uma vez que o atual estado da área de estudo remete às condições supracitadas nesta introdução e, portanto, cabe a investigação para compreensão das condições físico-naturais da bacia hidrográfica do Ribeirão do Escalvado. Do mesmo modo, justifica-se em razão dos produtos cartográficos desenvolvidos serem capazes de auxiliar possíveis intervenções públicas no gerenciamento da área de estudo.

\section{ÁREA DE ESTUDO}

A bacia do ribeirão do Escalvado (Figura 1), situa-se no município de Santa Cruz do Escalvado-MG e caracteriza-se por ser uma sub-bacia do Rio Doce. Possui área de $71,11 \mathrm{~km}^{2}$ com altitudes que variam entre $300 \mathrm{~m}$ e $678 \mathrm{~m}$ acima do nível mar. A economia da população que habita a bacia baseia-se na atividade agropecuária, como a produção de culturas temporárias como cana-de-açúcar, mandioca, milho feijão e amendoim, já cultura permanente se dá pelo plantio de bananas (IBGE, 2021). A pastagem ocorre em detrimento da criação de gado onde há produção de leite para empresas de laticínios de cidades vizinhas. 
Figura 1: Mapa de localização da bacia do ribeirão do Escalvado

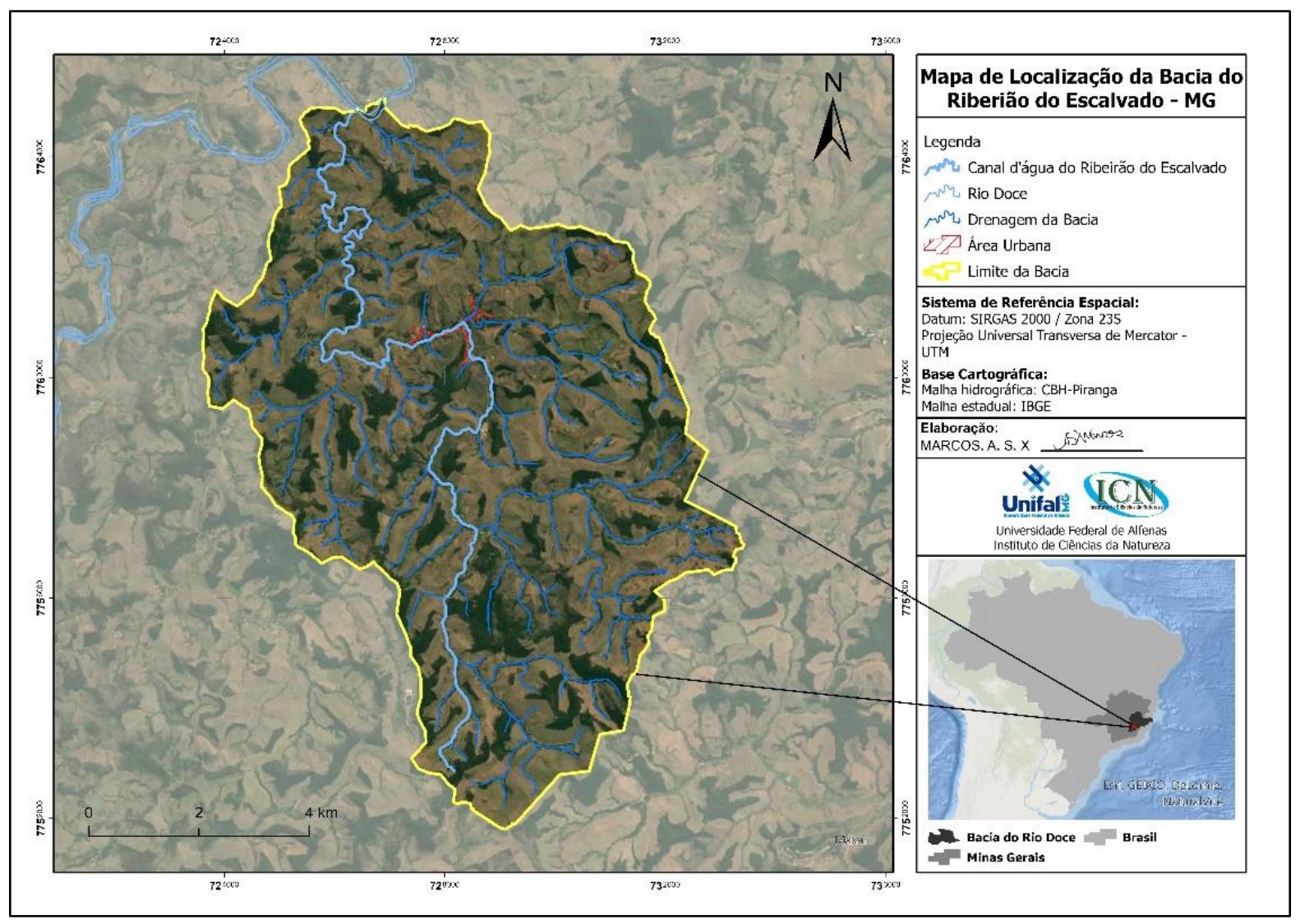

O relevo é caracterizado pelas serras e planaltos do leste e sudeste mineiro, submetidos à ação de processos morfogenéticos, onde as feições geradas na região condizem com aspectos litológicos e oscilações climáticas mesozóicas e cenozóicas (ACHÃO, 1991).

A vegetação vincula-se ao bioma da mata atlântica, composta por florestas ombrófilas e florestas estacionais semideciduais e deciduais (SOUZA; TOLEDO; FERNANDES FILHO, 2009). O clima segundo classificação de Köppen (1936) é subtropical úmido com inverno seco e verão quente (Cwa) (ALVARES et al., 2013).

MATERIAIS

Foram utilizados para o trabalho as seguintes bases cartográficas: 
- Imagens de radar SRTM com resolução espacial de 30 metros, disponibilizado da base de dados da United States Geological Survey(USGS) (https://earthexplorer.usgs.gov/);

- Imagens de satélite Sentinel-2 (bandas 8, 4, 3, 2 e 1), datadas do dia 11/08/2021 com resolução espacial de 10m, disponibilizadas pelo plugin "Living Atlas" do ArcGis Pro 2.8.1;

- Shapefile da Geologia (escala 1:1.000.000), disponibilizadas na base de dados conjunta da Companhia de Desenvolvimento Econômico de Minas Gerais (Codemig) e Companhia de Pesquisa de Recursos Minerais (CPRM) (http://www.portalgeologia.com.br/index.php/mapa/);

- Shapefile da Hidrografia (escala 1:50.000), disponibilizado pela Consórcio de Bacia Hidrográfica do Piranga (CBH-Piranga);

- Shapefile das classes de solos (escala 1:5.000.000), disponibilizado na base de dados da Empresa Brasileira de Pesquisa Agropecuária (EMBRAPA, 2006) (http://geoinfo.cnps.embrapa.br/);

\section{MÉTODOS}

O método selecionado para obtenção dos índices de fragilidade potencial e emergente baseou-se nas publicações de Ross (1994, 2012), que utiliza como variáveis a declividade, dissecação do relevo, classes de solo, precipitação, litologia e uso e ocupação da terra. O grau de fragilidade para cada classe das variáveis varia entre muito fraco, fraco, médio, forte e muito forte.

No presente estudo ocorreram três adaptações: 1) a variável de precipitação não foi inserida no cruzamento de dados, uma vez que ao longo da bacia não há nenhuma alteração significativa; 2) a declividade foi classificada a partir da metodologia proposta pela EMBRAPA (2006); 3) as classes de fragilidade de litologia foram adaptadas a partir da proposta de Crepani et al. (2001). 
Para realização do cruzamento de dados das variáveis foi utilizado o método de Analytic Hierarchy Process (AHP), feito por meio do software ArcPro 2.8.1. Neste contexto, para a determinação da fragilidade potencial considerou-se apenas a características físicas-naturais da bacia, sendo: declividade (peso 30), dissecação do relevo (peso 30), classes de solo (peso 20) e litologia (peso 20); obtendo o valor 100 no somatório total.

Enquanto para a determinação da fragilidade emergente, utilizou-se o resultado da fragilidade potencial correlacionado com aspectos derivados das intervenções antrópicas, representadas neste caso, pela variável do uso da terra. O peso atribuído para o cruzamento das duas variáveis que geraram o mapa de fragilidade emergente foi de 50 para cada.

\section{PROCEDIMENTOS METODOLÓGICOS PARA DETERMINAÇÃO DAS VARIÁVEIS}

Este tópico elucida os procedimentos metodológicos adotados para a obtenção de cada variável utilizada para o cálculo do índice de fragilidade ambiental.

Para o desenvolvimento do mapa das classes pedológicas da bacia, foi utilizado a base de dados disponibilizada pelo mapeamento realizado pela EMBRAPA (2006) com escala 1:5.000.000. Para a classificação de fragilidade de cada classe de solo usou-se a escala proposta por Ross (2012).

Para caracterização dos litotipos da bacia foram utilizados dados disponibilizados no projeto Portal da Geologia com escala 1:1.000.000 (CPRM; CODEMIG, 2014). Salienta-se que nesta base de dados foi realizada uma modificação, vinculada à adição de outro componente litológico (Granulito Pedra Dourada) identificado por Brandalise (1991) e mapeado por esta pesquisa. Para a classificação de fragilidade de cada litotipo utilizou-se a escala de vulnerabilidade proposta por Crepani et al. (2001), correlacionando-a com a hierarquia proposta por Ross (2012). 
Salienta-se que a metodologia de classificação proposta por Crepani et al. (2001) não envolve variações de gnaisses que estão presentes na bacia do Ribeirão do Escalvado, portanto, fez-se necessário adaptações. A primeira corresponde ao ortognaisse e ao granulito pedra dourada, sendo classificados com peso 1 (muito fraca), devido a sua composição mineralógica oferecer maior resistência ao intemperismo. Enquanto os paragnaisses foram classificados com peso 2 (fraca) em razão de possuírem intercalações ricas cálcio, vulneráveis à dissolução química.

Para obtenção das classes de declividade utilizou-se MDE gerado a partir de imagens de radar STRM com resolução espacial de $30 \mathrm{~m}$. O processamento deste arquivo raster no ArcPro 2.8.1 foi realizado utilizando-se as ferramentas do "3D Analyst", sendo o comando "slope" realizador do cálculo de declividade. A reclassificação dos dados gerados pelo "slope" foi realizada por meio do comando "reclassify", seguindo as classes proposta pela EMBRAPA (2006). Para a classificação de fragilidade de cada classe de declividade usou-se a escala proposta por Ross (2012).

A elaboração do índice de dissecação do relevo foi produzida a partir da metodologia de Guimarães et al. (2017). Estes autores, a partir de uma revisão do método de Ross $(1994,2012)$, publicam uma proposta de automatização do índice de dissecação do relevo, utilizando-se de MDE's para a caracterização morfométrica. Neste sentido, o procedimento de desenvolvimento do índice foi realizado a partir de quatro etapas: 1) tratamento e preparação do MDE; 2) mapeamento do grau de entalhamento dos vales; 3) mapeamento da dimensão interfluvial média; e 4) cálculo dos valores de dissecação do relevo.

Seguindo estes procedimentos, o grau de entalhamento foi reclassificado em: 0 a 20 m (10); 20 a 40 m (20); 40 a 80 m (30); 80 a 160 m (40); > 160 m (50). Enquanto para a dimensão fluvial média procedeu-se a reclassificação da seguinte forma: 0 a 250 m (5); 250 a 750 m (4); 750 a 1750 m (3); 1750 a 3750 m (2); > 3750 
m (1) (ROSS, 2012; Guimarães et al., 2017). O passo a passo relativo aos procedimentos de geoprocessamento para geração do índice em ambiente SIG, podem ser encontrados na pesquisa de Marcos (2021).

Por fim, salienta-se que o mapa de uso da terra da bacia foi elaborado por meio do método de classificação supervisionada (PEREIRA et al., 2011) a partir da Máxima Verossimilhança (RIBEIRO; BAPTISTA; BIAS, 2007). Para tanto, foram utilizadas imagens do satélite Sentinel-2, datadas do dia 11/08/2021 com resolução espacial de 10m, disponibilizadas pelo plugin "Living Atlas" do ArcGis Pro 2.8.1. A composição escolhida foi a falsa cor envolvendo as bandas, as bandas 8 (NIR -Infravermelho próximo), 4 (Vermelha) e 3 (Verde). Para a classificação de fragilidade das classes de uso da terra foi utilizada a escala proposta por Ross (2012).

Posteriormente, a fim de verificar a acurácia do uso da terra, aplicou-se o índice de Kappa seguindo a proposta de Landis e Koch (1977), calculado por matrizes de confusão ou matrizes de erro através da função "Compute Confusion Matrix" (RODRIGUES; ROCHA; PEREZ FILHO, 2007).

\section{RESULTADOS E DISCUSSÕES}

\section{LITOLOGIA}

A interpretação da litologia em relação à fragilidade da bacia influencia diretamente no entendimento na formação do relevo, desenvolvimento das características das classes de solos e incidência dos processos de erosão/movimentos de massas que agravam a degradação das encostas das bacias hidrográficas (GUERRA; CUNHA, 2000). A Figura 2 ilustra e localiza às unidades geológicas da bacia com os 3 litotipos identificados (Figura 2). 
Figura 2: Litologia da bacia

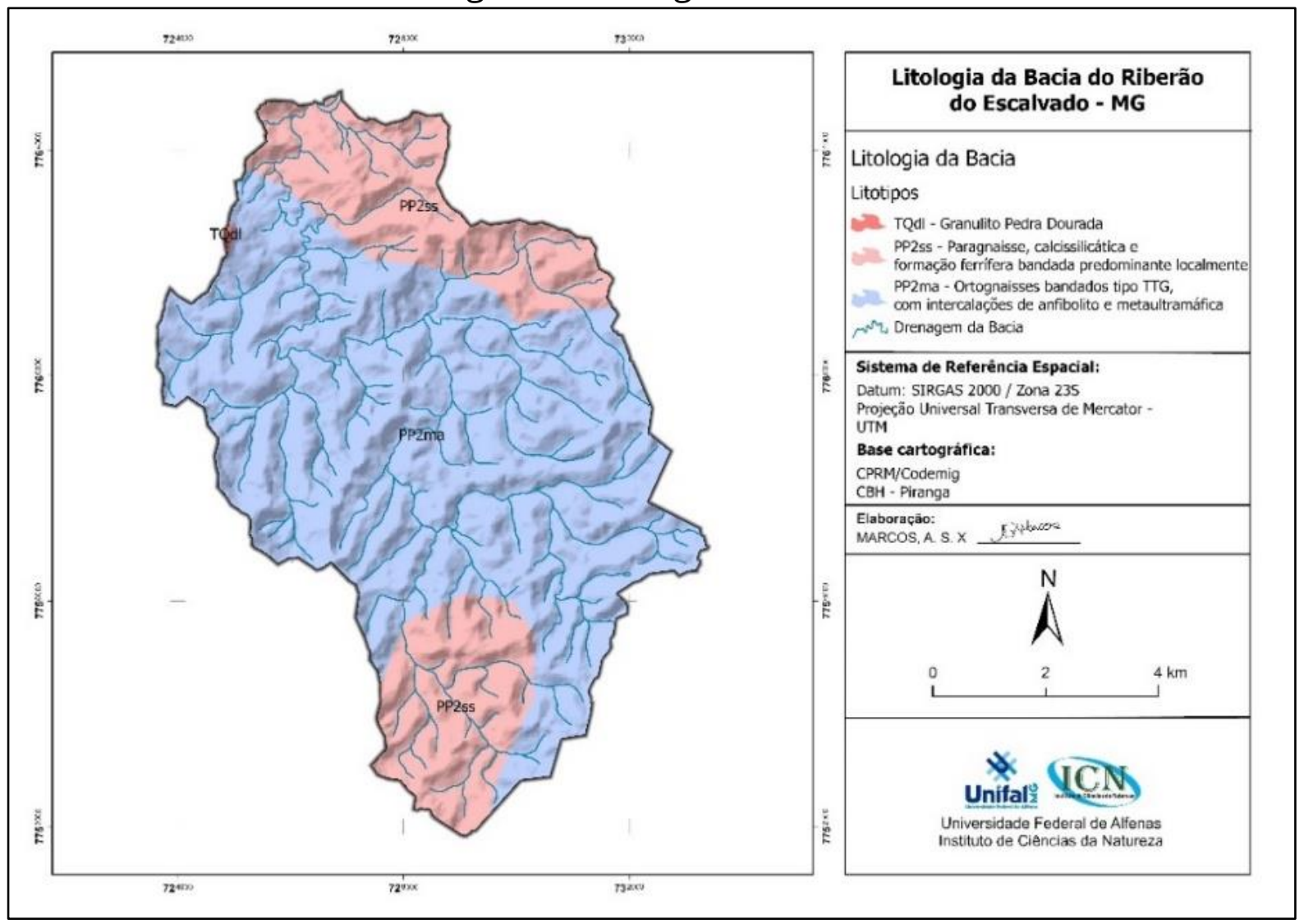

A Tabela 1 detalha o tamanho da área abrangente e o grau de fragilidade atribuído a cada litologia (Tabela 1).

Tabela 1: Características litológicas e atribuição de fragilidade

\begin{tabular}{|c|c|c|c|c|c|}
\hline Unidade & $\begin{array}{l}\text { Tipo de } \\
\text { Rocha }\end{array}$ & Litotipo & Fragilidade & $\begin{array}{l}\text { Área } \\
\left(\mathrm{km}^{2}\right)\end{array}$ & $\begin{array}{c}\text { Área } \\
(\%)\end{array}$ \\
\hline $\begin{array}{c}\text { São Sebastião } \\
\text { do Soberbo }\end{array}$ & Metamórfica & $\begin{array}{l}\text { Paragnaisse, calcissilicática e } \\
\text { formação ferrífera bandada } \\
\text { predominante localmente }\end{array}$ & $\begin{array}{c}2 \\
\text { (Fraca) }\end{array}$ & 20,9 & 28,9 \\
\hline $\begin{array}{l}\text { Complexo } \\
\text { Mantiqueira }\end{array}$ & Metamórfica & $\begin{array}{l}\text { Ortognaisses bandados tipo } \\
\text { TTG, com intercalações de } \\
\text { anfibolito e metaultramáfica }\end{array}$ & $\begin{array}{c}1 \\
\text { (Muito fraca) }\end{array}$ & 51,4 & 71,0 \\
\hline $\begin{array}{l}\text { São Sebastião } \\
\text { do Soberbo } \\
\text { Grupo Dom } \\
\text { Silvério }\end{array}$ & Metamórfica & $\begin{array}{l}\text { Rochas granulíticas associadas à } \\
\text { paragnaisses, com presença de } \\
\text { ortopiroxênio, granada, } \\
\text { sillimanita e espinélio }\end{array}$ & $\begin{array}{c}1 \\
\text { (Muito fraca) }\end{array}$ & 0,12 & 0,2 \\
\hline
\end{tabular}

Fonte: Adaptado de Codemig/CPRM (2001) e Crepani et al. (2001).

\section{ÍNDICE DE DISSECAÇÃO DO RELEVO}


O entalhamento da bacia é representado por valores consideráveis (acima de 40 a $80 \mathrm{~m}$ ), atingindo $160 \mathrm{~m}$ em alguns setores (Figura 3A). Tal resultado se relaciona à forte ondulação que é presente no relevo da bacia, que junto ao mapa de declividade expõe a morfologia local e o entalhamento suscitado pela rede de drenagem. Com relação à dimensão interfluvial (Figura 3B), verifica-se morfologia representada por vales encaixados, com distância euclidiana dos interflúvios entre 0 e $250 \mathrm{~m}$ e 250 e $750 \mathrm{~m}$, típicos de terrenos mais declivosos com rugosidades significativas.

Figura 3: (A) Entalhamento da Bacia; (B) Dimensão interfluvial da bacia

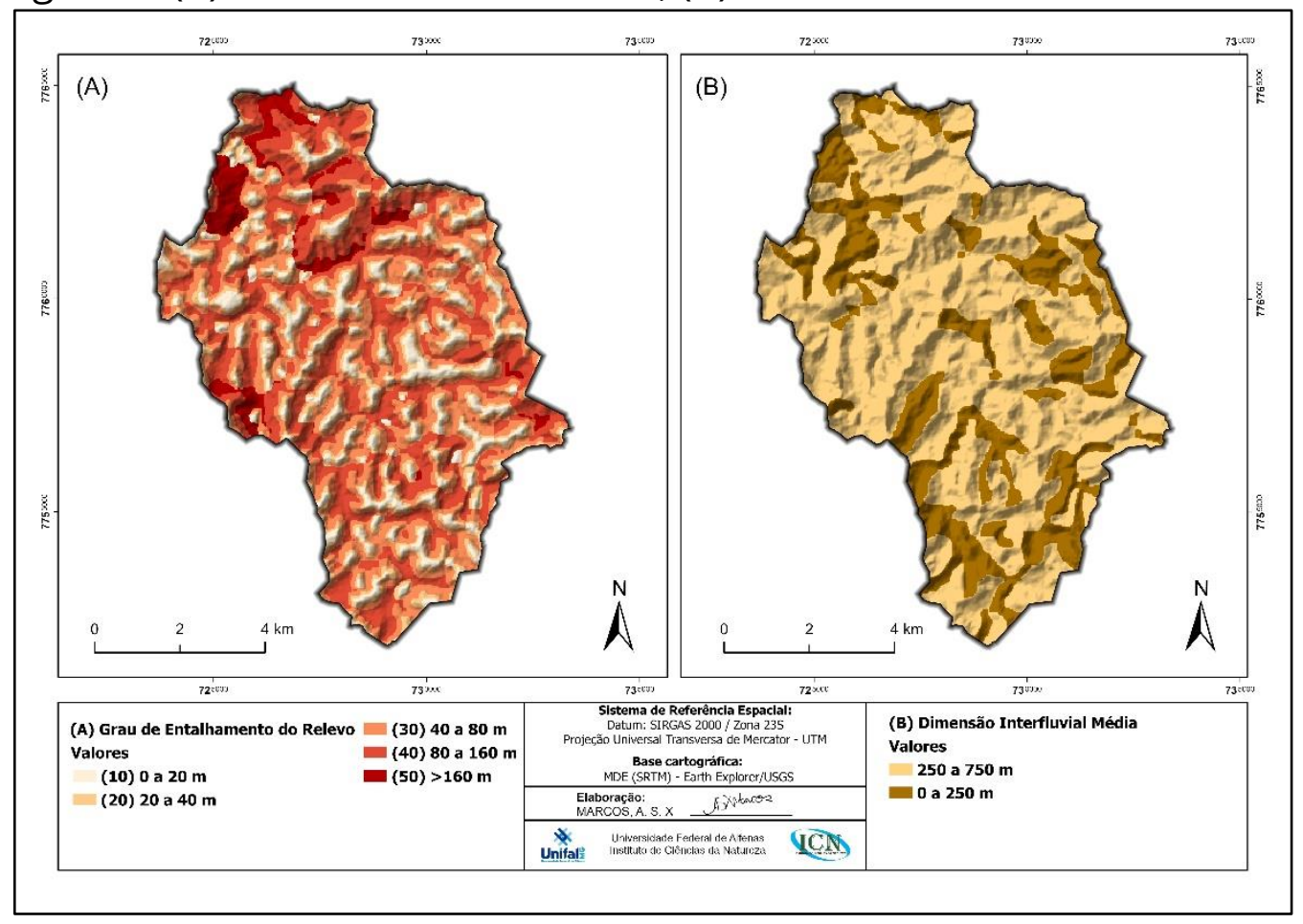

Por meio das variáveis de entalhamento e dimensão interfluvial foi possível classificar o índice de dissecação do relevo da bacia hidrográfica do ribeirão do Escalvado (Figura 4). A área apresenta valores de alta fragilidade que variam entre 14 e 55, representativos de vales encaixados e profundos, conforme elucidado por Guimarães et al. (2017). 
Figura 4: Fragilidade da dissecação do relevo presente na bacia

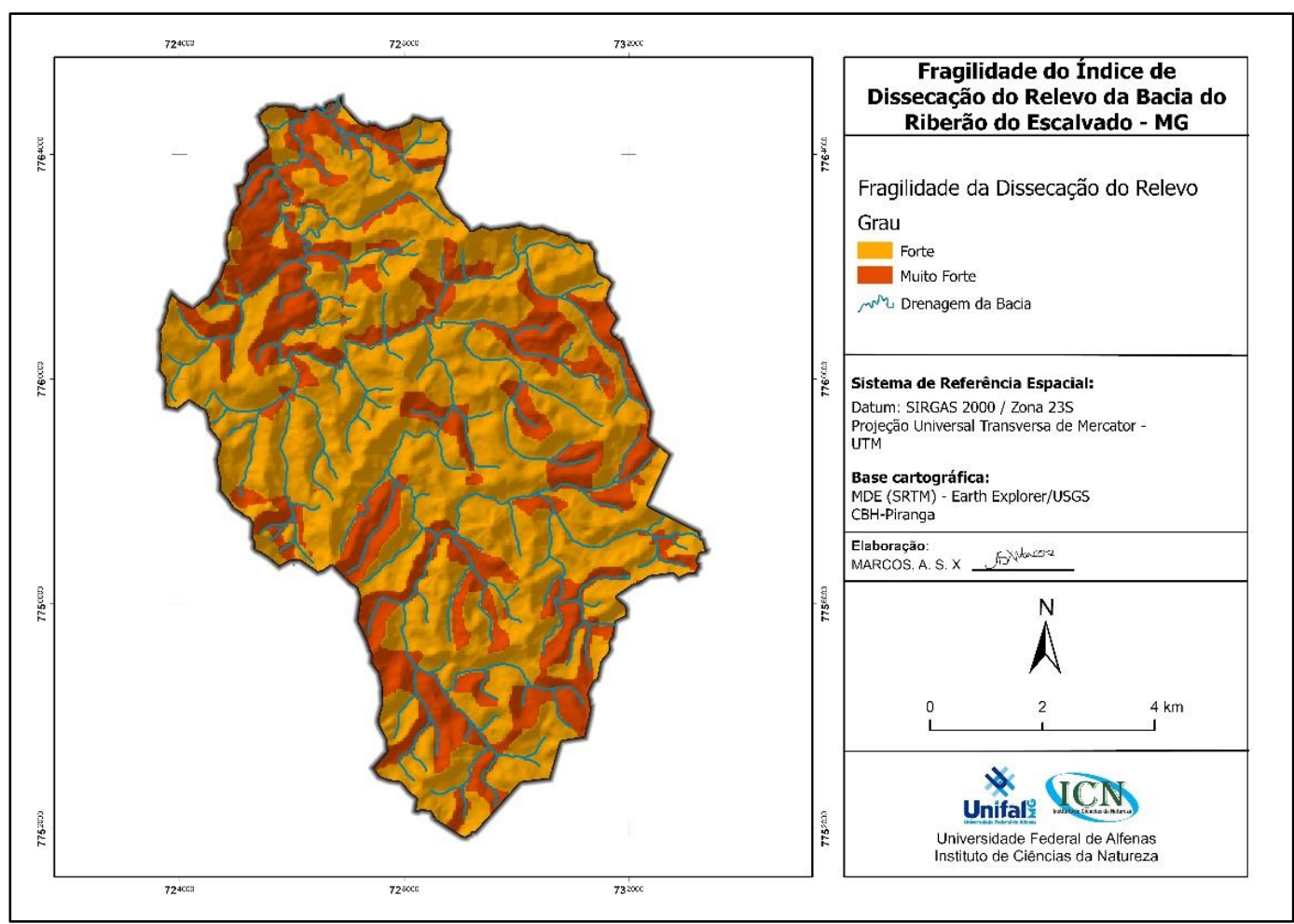

Assim, de acordo com a classificação proposta por Ross (1994; 2012), a bacia

apresenta padrão de dissecação de forte (4) para muito forte (5), com predomínio de vales em "V" encaixados e profundos. Neste sentido, a fragilidade relativa a esta variável constitui-se como muito forte para $28,4 \%$ da área da bacia e forte para oso demais setores $(71,6 \%)$ (Tabela 2$)$.

Tabela 2: Grau de fragilidade da dissecação do relevo e sua distribuição territorial

\begin{tabular}{c|c|c|c}
\hline Categorias Agrupadas & Fragilidade & Área $\mathbf{k m}^{2}$ & Área (\%) \\
\hline $14,24,34,44,54$ & (4) Forte & 51,0 & $71,6 \%$ \\
$15,25,35,45,55$ & (5) Muito forte & 20,3 & $28,4 \%$ \\
\hline
\end{tabular}

Fonte: Adaptado de Ross (2012)

No mapeamento cabe destacar a relação do tipo litológico com o relevo característico da bacia, como o predomínio da espacialização da dissecação muito 
forte em áreas que estão concentradas os paragnaisses, estes como supracitado serem mais suscetíveis ao intemperismo.

O predomínio de uma vasta ondulação e dissecação do relevo segue em conformidade com o que a literatura indica para a bacia do rio Doce, onde a área de estudo está inserida. Tal unidade é caracterizada por situar-se em ambiente com atividade tectônica ativa em clima úmido, dinâmica que propicia o desenvolvimento de relevos íngremes a partir da elevada capacidade hidrográfica e atuação conjunta dos processos de intemperismo, erosão e denudação (LEÃO et al., 2012).

\section{DECLIVIDADE}

A declividade calculada por meio do MDE e reclassificada com base na proposta da EMBRAPA (2006), exibe predominância de encostas e vertentes com relevo fortemente ondulado $(59,77 \%)$, seguida por morfologia ondulada $(25,22 \%)$, montanhosa ou escarpada (7,55\%), suavemente ondulada $(6,12 \%)$ e plana $(1,34 \%)$ (Tabela 3).

Tabela 3: Características de relevo, distribuição da declividade e fragilidade

\begin{tabular}{c|c|c|cc}
\hline Declividade (\%) & Tipo de Relevo & Fragilidade & Área $\left.\mathbf{( k m}^{\mathbf{2}}\right)$ & Área (\%) \\
\hline $0-3 \%$ & Plano & (1) Muito fraca & 0,94 & 1,34 \\
$3-8 \%$ & Suavemente ondulado & (2) Fraca & 4,30 & 6,12 \\
$8-20 \%$ & Ondulado & (3) Média & 17,72 & 25,22 \\
$20-45 \%$ & Fortemente ondulado & (4) Forte & 41,99 & 59,77 \\
$45->75 \%$ & Montanhoso/ Escarpado & (5) Muito forte & 5,30 & 7,55 \\
\hline
\end{tabular}

Fonte: Adaptado de EMBRAPA (2006)

Observa-se vasta ondulação e vertentes com altos declives (Figura 5).

As topografias escarpadas e montanhosas vinculam-se à afloramentos rochosos alçados em níveis altimétricos mais elevados, enquanto os menores declives estão diretamente associados à drenagem da bacia, especificamente em setores de planícies fluviais mais alargadas devido à divagação lateral dos cursos d'água (Figura 6). 
Importante destacar que terrenos com presença de declives acentuados, como observado na bacia do ribeirão do Escalvado (MG), quando associados às áreas de vegetação escassa, comumente trazem problemas de degradação. Esta relação explica a ocorrência de muitos processos erosivos lineares observados na bacia, a partir da intensificação do escoamento superficial em encostas desmatadas.

Figura 5: Relevo característico da bacia (área central)

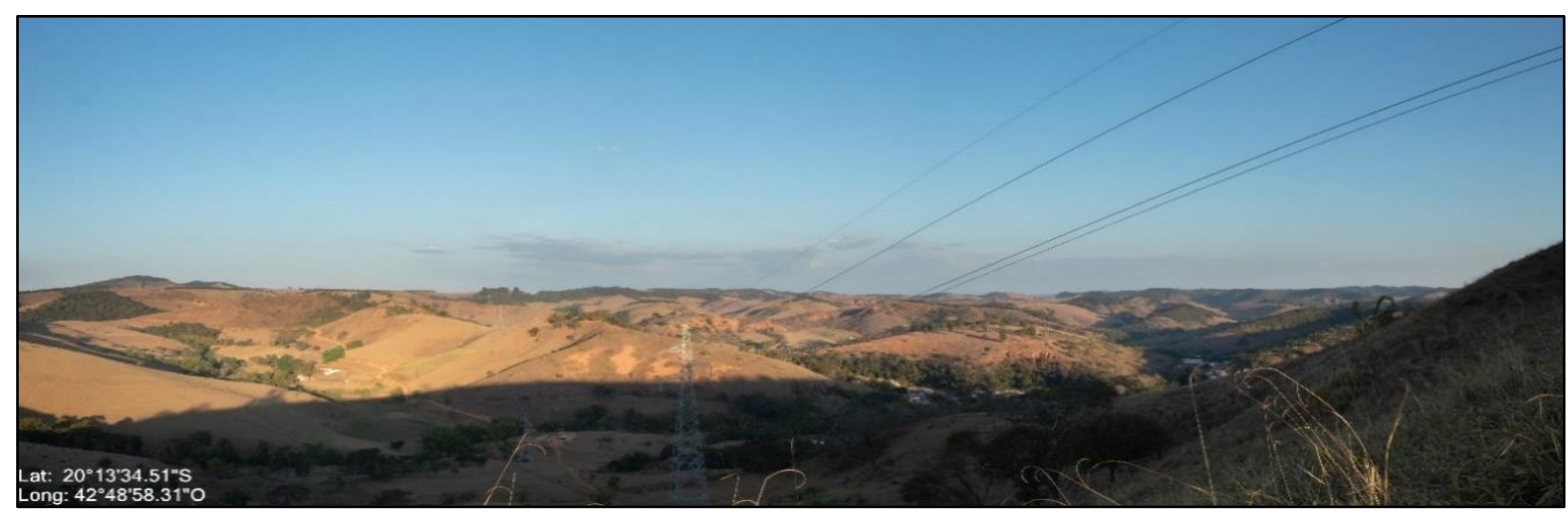

Fonte: MARCOS (2021) 
Figura 6: Declividade da bacia

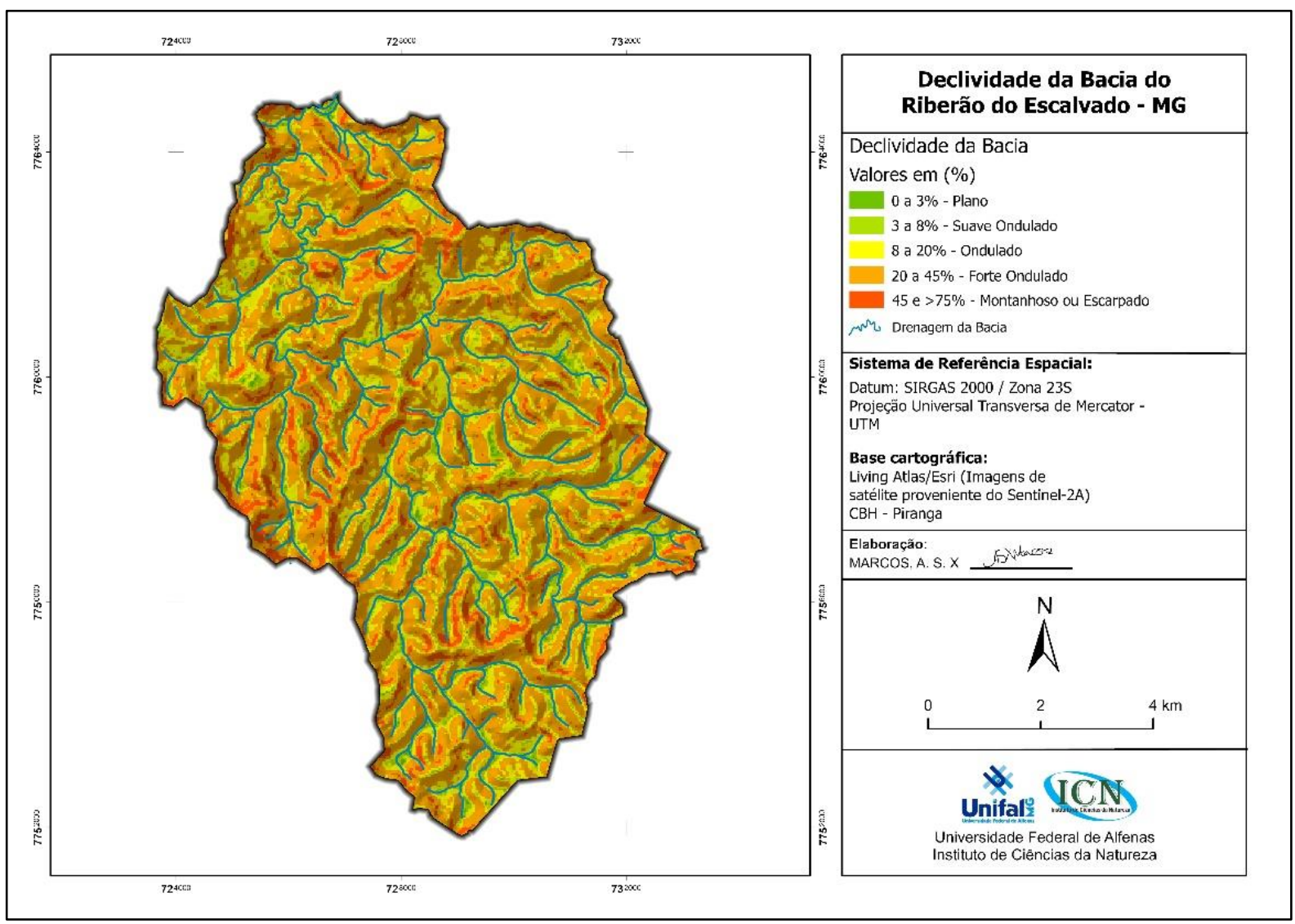

Soma-se a estes fatores, eventuais inundações na área urbana do município de Santa Cruz do Escalvado, situada nas margens do ribeirão homônimo em zona de fundo de vale. Pode-se citar como exemplo a forte chuva que atingiu a área urbana do município no ano de 2017, acarretando inúmeros problemas socioeconômicos (Figura 7). 
Figura 7: Inundação na área urbana de Santa Cruz do Escalvado em 2017
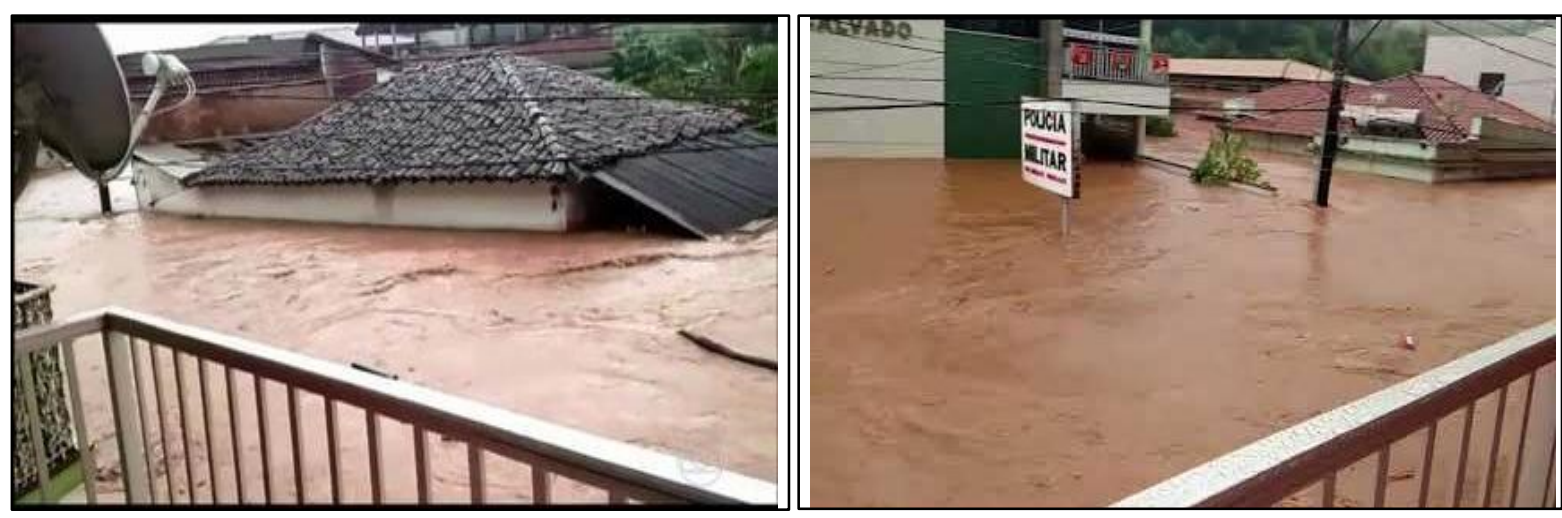

Fonte: PORTAL G1 (2021)

\section{PEDOLOGIA}

Segundo os dados da EMBRAPA (2006) a bacia é caracterizada por duas variações de solos, representadas pelo desenvolvimento de Latossolos VermelhoAmarelos Distróficos (14\% da área / com classe de fragilidade 1) e Argissolos Vermelhos Eutróficos (86\% da área / com classe de fragilidade 3) (Figura 8).

O desenvolvimento de Latossolos vincula-se a provável área de maior intemperismo na bacia, sua identificação condiz com o substrato litológico mais suscetível a ocorrência deste processo (paragnaisses). Enquanto os Argissolos vinculam-se à ambientes bem drenados e espacializam-se na maior parte da bacia, englobando o tipo de relevo forte ondulado identificado pelo mapa de declividade. A Tabela 4 atribui a sua distribuição territorial e o grau de fragilidade atribuído.

Tabela 4: Classes de solos, distribuição na bacia e fragilidade atribuída

\begin{tabular}{c|c|c|c|c}
\hline Tipos de solo & Sigla & Fragilidade & Área (km²) & Área (\%) \\
\hline Latossolos Vermelho-Amarelos Distroficos & LVAd & 1 & 10,18 & $14 \%$ \\
Argissolos Vermelhos Eutroficos & PVe & 3 & 61,23 & $86 \%$ \\
\hline
\end{tabular}


Figura 8: Pedologia da bacia

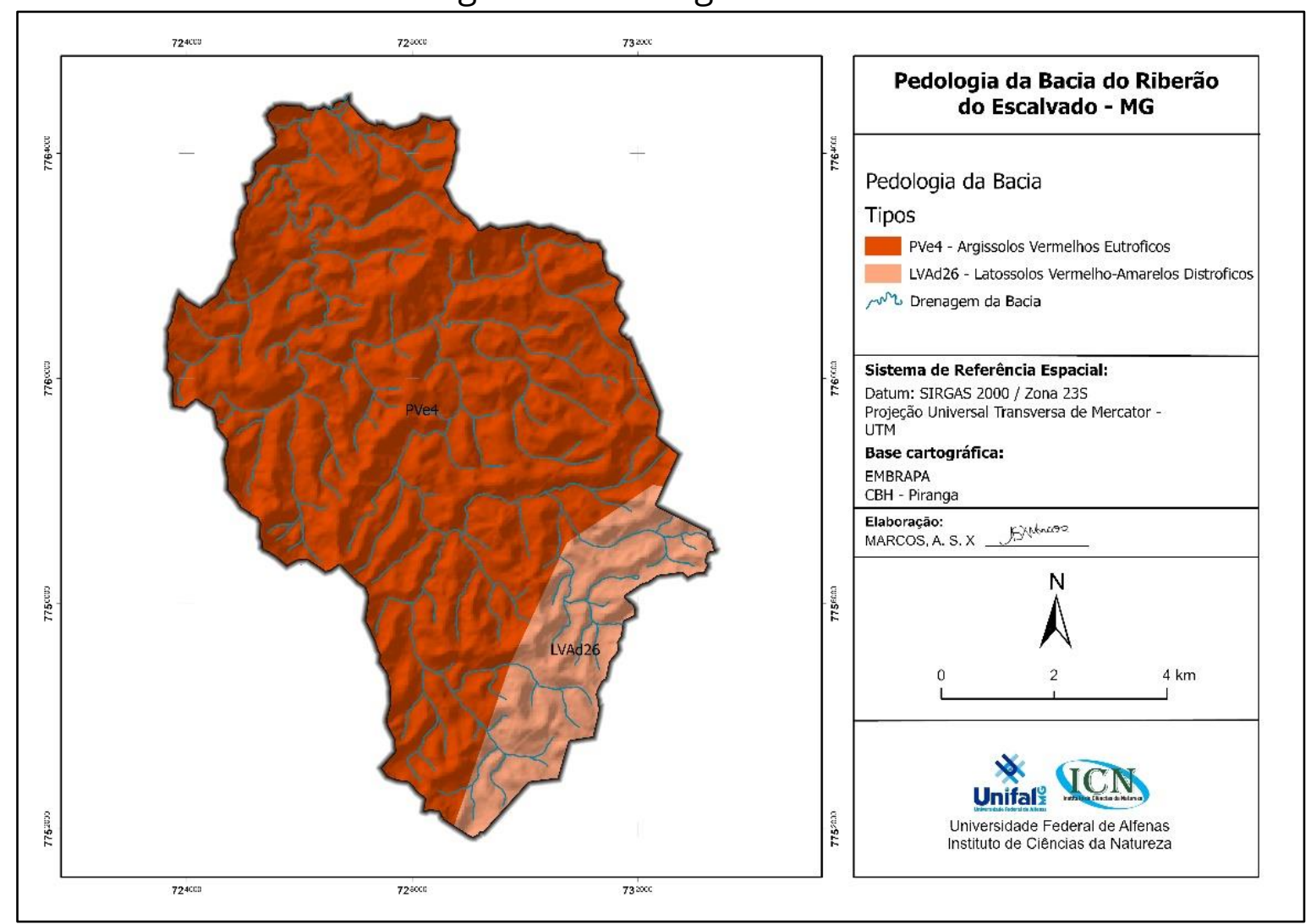

A concentração de argissolos nos setores de relevos fortemente ondulados potencializa a ocorrência de erosão laminar, esta identificada como ravinas em vertentes da bacia (Figura 9).

Figura 9: Presença de ravinas sobre a vertente do córrego do quilombo

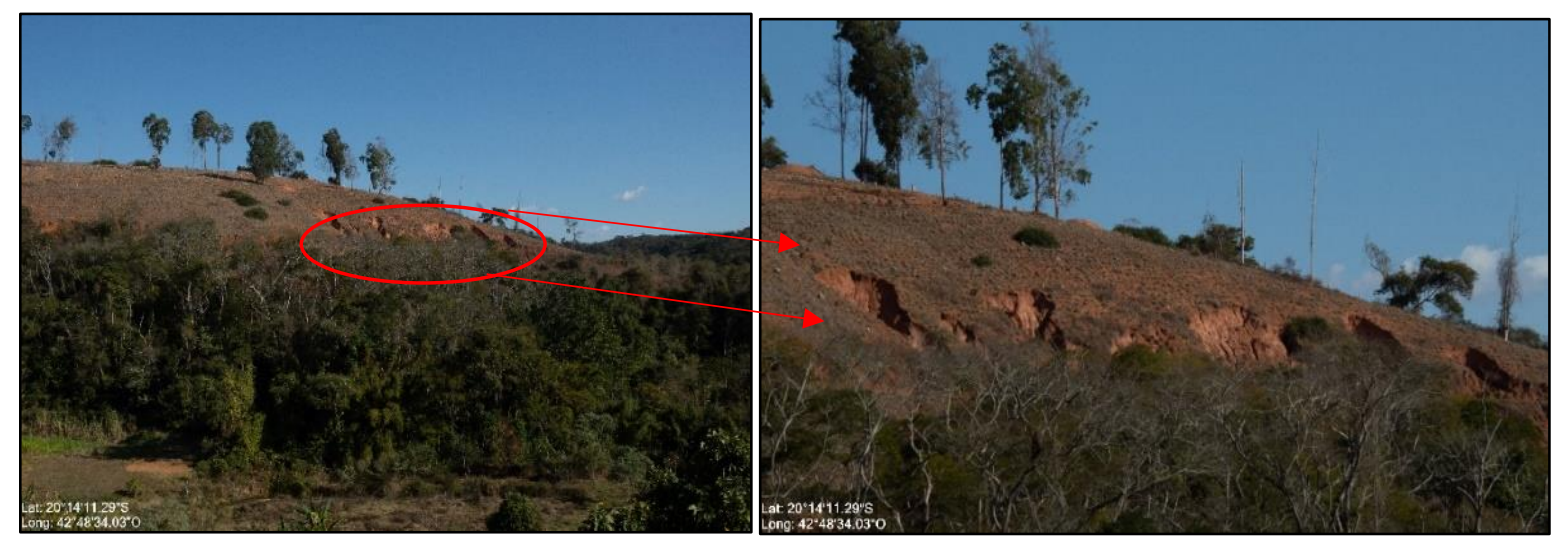

Fonte: MARCOS (2021) 
A formação de tais processos erosivos, possivelmente configura-se como reflexo da organização dos perfis pedológicos, vinculada a horizonte arenoso superficial e horizonte subjacente correlacionada à acumulação de argila em profundidade (Bt), disposição típica da classe pedológica homônima.

\section{USO DA TERRA}

A classificação supervisionada do uso da terra da bacia obteve a acurácia de 0,75 relativa ao índice de Kappa e, segundo Landis e Koch (1977), esse valor é interpretado como uma exatidão muito boa. O uso da terra da bacia do ribeirão do Escalvado é representado pelas seguintes classes: (3,11\%), agricultura (1,25\%), mancha urbana (0,22\%) e corpos d'água (0,03\%). Detalhadamente, a tabela 5 e a figura 10 evidenciam à distribuição de cada classe com os respectivos graus de fragilidade atribuídos a cada uma (Tabela 5).

Tabela 5: Características do uso da terra, distribuição e fragilidade atribuída

\begin{tabular}{c|ccc}
\hline Classes & Fragilidade & $\begin{array}{c}\text { Área } \\
\left(\mathrm{km}^{2}\right)\end{array}$ & Área (\%) \\
\hline Solo exposto & (5) Muito forte & 2,26 & $3,11 \%$ \\
Agricultura & (5) Muito forte & 0,91 & $1,25 \%$ \\
Mancha Urbana & (5) Muito forte & 0,16 & $0,22 \%$ \\
Pastagem & (4) Forte & 48,1 & $66,21 \%$ \\
Vegetação & (1) Muito fraca & 21,2 & $29,18 \%$ \\
Corpos d'água & (0) & 0,0194 & $0,03 \%$ \\
\hline
\end{tabular}

Por meio do produto cartográfico desenvolvido, é possível observar a espacialização das classes descritas (Figura 10).

Verifica-se que a predominância se vincula à pastagem (66,21\%), um cenário observado em grande parte de todo território mineiro e não diferente na bacia do ribeirão Escalvado, ocupando setores da vertente e planície de inundação adjacentes ao curso d'água homônimo (Figura 11). 
Posteriormente, observa-se maior porcentagem areal associada às vegetações remanescentes $(29,18 \%)$, presentes principalmente em alguns topos de morros, enquanto as conseguintes classes de uso da terra são vinculadas às categorias de solo exposto (3,11\%), agricultura $(1,25 \%)$ e mancha urbana $(0,22 \%)$ e, correspondem, ao maior grau de fragilidade inerente a esta variável (muito forte).

As categorias vinculadas ao solo exposto correlacionam-se com setores onde houve queimadas para colheita da cana-de-açúcar, enquanto os setores com agricultura associam-se a esta última e ao eucalipto. A mancha urbana está alocada diretamente sob o leito do ribeirão do Escalvado, onde frequentemente observa-se despejo de dejetos, rejeitos líquidos e sólidos no curso d'água.

Figura 10: Uso da terra da bacia

\begin{tabular}{|l|l|} 
Uso do Solo em 2021 na Bacia \\
do Riberão do Escalvado - MG
\end{tabular}


Figura 11: Área de pastagem na vertente e na planície de inundação

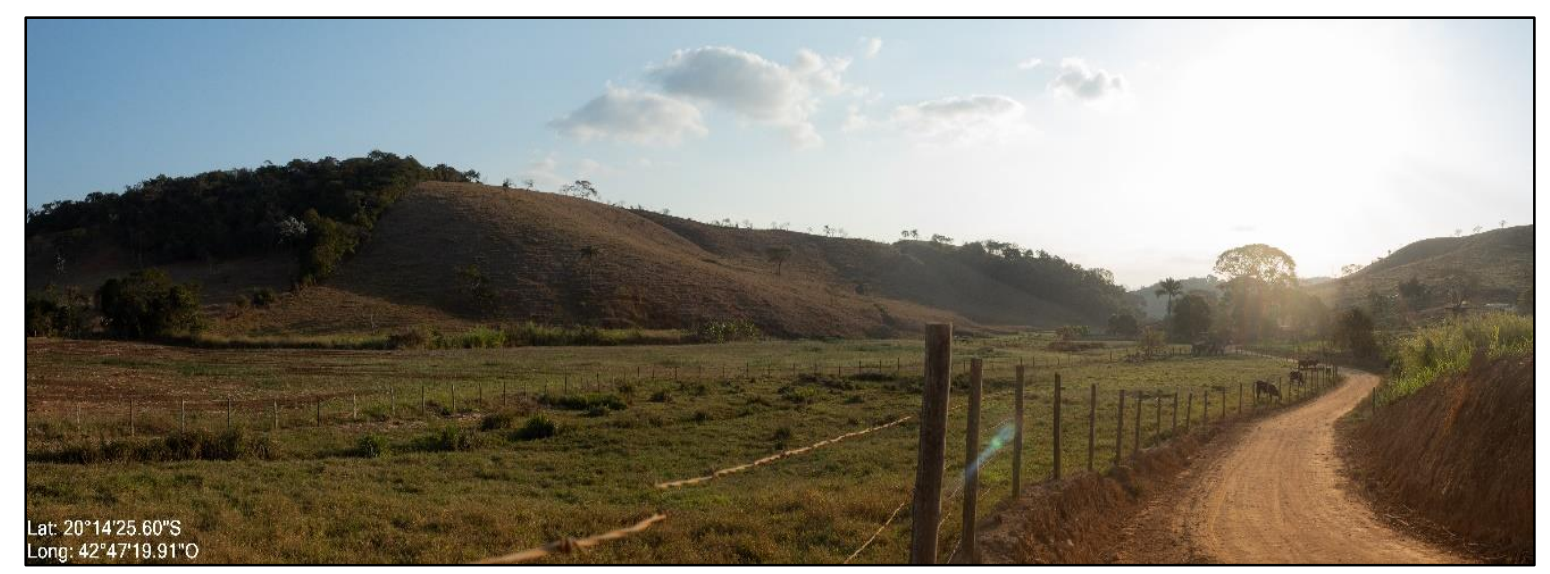

Fonte: MARCOS (2021)

Neste sentido, o uso da terra observado na bacia remete ao histórico de ocupação sem muitas práticas conservacionistas desde o declínio do ciclo do ouro na região. Quando não há agriculturas de cultivo curto com prática de queimadas, há vastos campos de pastagem, que aos poucos também influenciam no desenvolvimento de processos erosivos dos solos, bem como na modificação das formas do relevo. Esta conjuntura propicia maior fragilidade ao sistema ambiental em face das suas características genéticas naturais.

\section{FRAGILIDADE POTENCIAL}

Com base nos mapas das caraterísticas físicas e naturais da área de estudo (variáveis), associou-se por meio da sobreposição ponderada os mapas de pedologia, litologia, dissecação do relevo e declividade. Este processamento de dados resultou na determinação da fragilidade potencial da bacia do ribeirão do Escalvado, ou seja, a fragilidade natural que a área de estudo possui (Figura 12). 
Figura 12: Fragilidade potencial da bacia

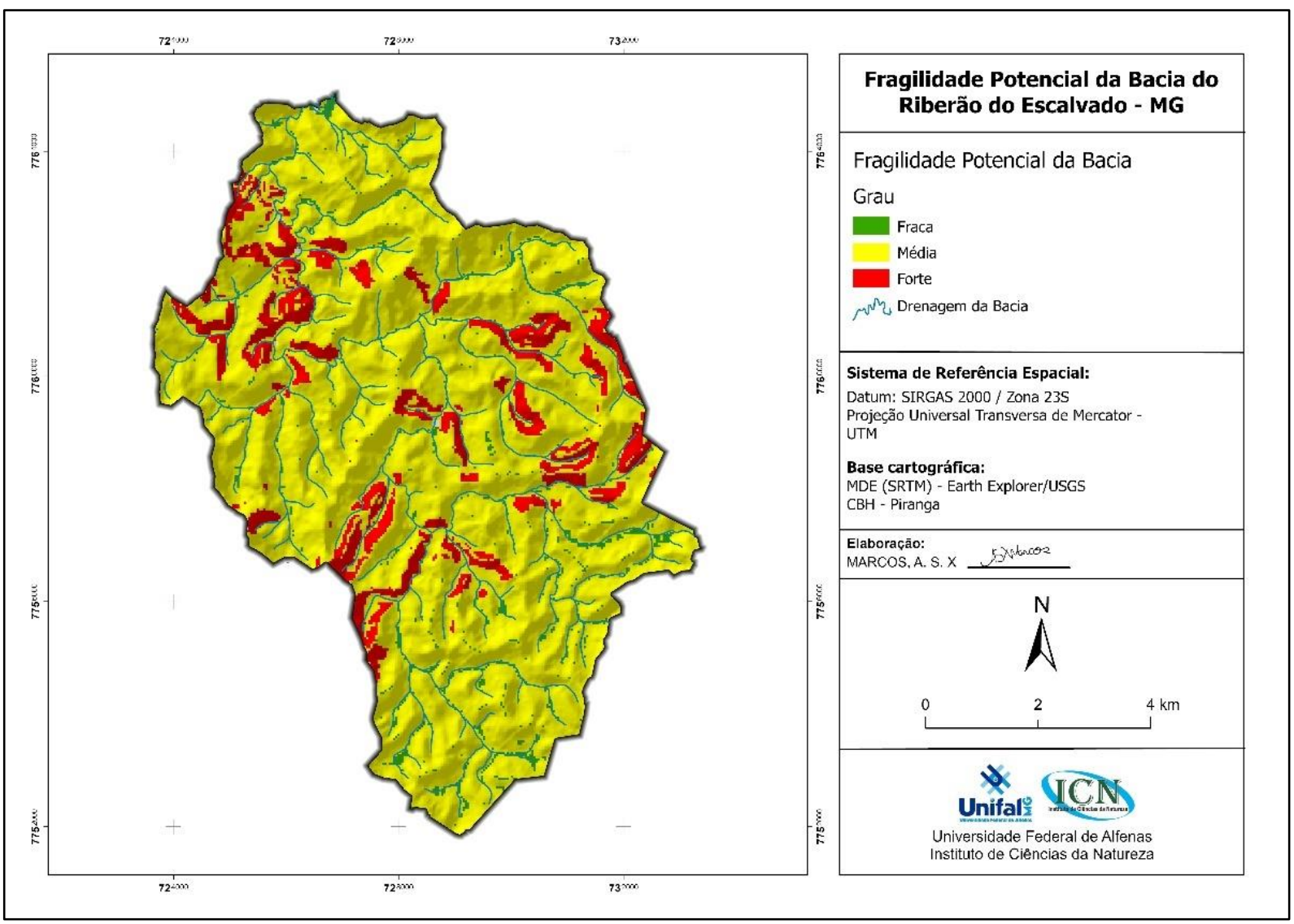

Nota-se que a bacia apresenta três níveis de fragilidade potencial de acordo com o resultado obtido por meio da aplicação da metodologia proposta, cerca de 2,3\% para a classe fraca, 86,49\% para a média e 11,38\% para a forte (Tabela 6). Observa-se que a classe de alta fragilidade potencial exibiu relações diretamente associadas às variações da dissecação do relevo categorizada como muito forte ( $28,4 \%$ da área total da bacia) e com a declividade de relevos montanhosos e escarpados (respectivamente 7,29\% e 0,26\% da área total da bacia).

Tabela 6: Fragilidade potencial e sua distribuição na bacia

\begin{tabular}{c|c|c}
\hline Fragilidade emergencial & Área $\left.\mathbf{( k m}^{2}\right)$ & Área (\%) \\
\hline (2) Fraca & 1,5 & 2,13 \\
(3) Média & 60,8 & 86,49 \\
(4) Forte & 8 & 11,38 \\
\hline
\end{tabular}


Salienta-se que estas variáveis também apresentaram maiores fragilidades em seus mapeamentos individuais, estando, portanto, mais suscetíveis a ocorrência de processos de degradação ambiental. Assim, devem constituir pontos estratégicos de monitoramento ambiental, pois tendem a ser mais suscetíveis a ocorrência de processos de degradação ambiental.

Ademais, nota-se que os pontos de fragilidade média estão direcionados às áreas de menores declives e relevos ondulados, enquanto as áreas que apresentaram fraca fragilidade potencial correlacionam-se com setores de drenagem que em seu entorno apresentam remanescentes de vegetação nativa.

\section{FRAGILIDADE EMERGENTE}

Com a fragilidade potencial definida, correlacionou-se por meio da sobreposição ponderada, a variável uso da terra, objetivando determinar à fragilidade emergente da bacia em face às ações antrópicas. O resultado indica um predomínio de fragilidade emergente forte (4), representada por de 64,85\% do território da bacia do ribeirão do Escalvado (Tabela 7 e Figura 13).

Os setores de fragilidade muito forte (5), distribuídos em $8,11 \%$ da área total da bacia (Tabela 7), estão ligados diretamente à intensidade da dissecação do relevo, declividade e aos setores de solos expostos, evidenciados pelo mapa de uso da terra.

Os setores associados às classes de fragilidade potencial forte e muito forte, sem devidas práticas conservacionistas, apresentam maior suscetibilidade perante a incidência de erosões, acarretando maior transporte de sedimentos ao longo da encosta, com posterior deposição nos cursos d'água. Dinâmica que pode propiciar a ocorrência de assoreamento da drenagem local (Figura 13). 
Tabela 7: Fragilidade emergente e sua distribuição na bacia

\begin{tabular}{c|c|c}
\hline Classes da fragilidade potencial & Área $\left.\mathbf{( k m}^{2}\right)$ & Área (\%) \\
\hline (1) Muito fraca & 0,62 & $0,88 \%$ \\
(2) Fraca & 15,1 & $21,47 \%$ \\
(3) Média & 3,3 & $4,69 \%$ \\
(4) Forte & 45,6 & $64,85 \%$ \\
(5) Muito forte & 5,7 & $8,11 \%$ \\
\hline
\end{tabular}

Figura 13: Fragilidade potencial da bacia

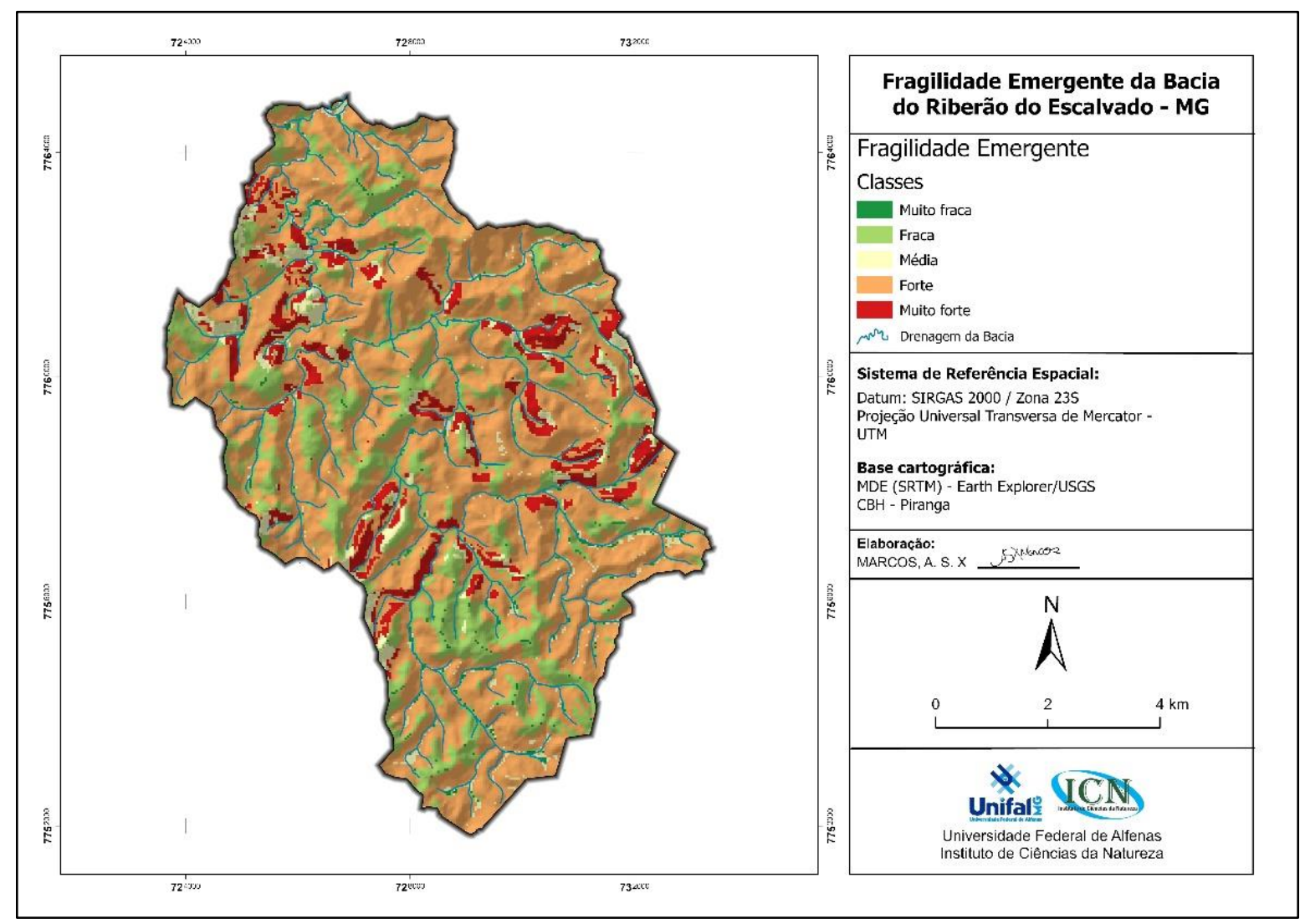

A cidade de Santa Cruz do Escalvado, circundada por um grau de forte fragilidade, apresenta eventuais problemas de inundações em períodos de chuvas torrenciais, devido à ausência de vegetação e encostas com altos declives. Características que intensificam o escoamento superficial na bacia.

Por outro lado, a classe fraca (2) é a segunda com maior frequência na bacia $(21,47 \%)$, influenciada pela presença de vegetações remanescentes. Um detalhe 
da classificação desta classe deve-se ser ressaltado, as matas em sua maior parte estão circundadas por pastagem, tanto que a classe de fragilidade média (cerca de 4,69\%) se espacializa nestes limites, indicando, portanto, áreas que futuramente podem sofrer distúrbios ambientais caso ocorra a supressão da vegetação.

\section{CONCLUSÕES}

Os resultados obtidos por meio da pesquisa foram satisfatórios, uma vez que houve respostas a toda problemática discutida ao longo do texto. A fragilidade potencial e emergente da bacia do ribeirão do Escalvado apresentouse condizentes tanto com sua historicidade relacionada à ocupação da sociedade, quanto à evolução geocronológica do sistema natural.

O mapeamento do uso da terra possibilitou a compreensão da ocupação territorial, caracterizada por sucessivos desmatamentos provocados pela expansão urbana e agrícola. Fato recorrente na história da zona da mata mineira, configurando-se a pastagem como a classe com maior domínio na bacia.

Paralelamente a estes fatores, verificou-se que a bacia do ribeirão do Escalvado apresenta características físicas-naturais condizentes com o que a literatura nacional indica para a bacia do Rio Doce, representada por relevos acidentados e resultantes da elevada dissecação fluvial. Fatores responsáveis por desenvolverem vertentes com declividades acentuadas que, sob influência de determinado uso da terra, apresentam-se amplamente suscetíveis a ocorrência de processos erosivos lineares, laminares e por pisoteio de gado.

Por fim, ressalta-se que a análise das variáveis naturais e antrópicas possibilitaram a confecção de produtos cartográficos que, mediante ao que foi exposto, evidenciam o agravamento da fragilidade da bacia quando as variáveis são correlacionadas. Elucidam, sobretudo, setores com altas fragilidades, agravados pela presença majoritária de pastagem e poucos remanescentes 
florestais. Deste modo, a análise indica que, futuramente, a configuração da fragilidade emergente possa ser agravada caso não haja uma maior preservação/gestão sustentável dos recursos naturais da bacia do ribeirão do Escalvado.

\section{REFERÊNCIAS BIBILIOGRÁFICAS}

ACHÃO, S. M. Geografia. In: BRANDALISE, L. A. Programa Levantamentos Geológicos Básicos do Brasil. Folha Ponte Nova, SF.23-X-B-II. Minas Gerais: CPRM, 1991. $161 \mathrm{p}$.

ALVARES, C. A.; STAPE, J. L.; SENTELHAS, P. C.; DE MORAES GONÇALVES, J. L.; SPAROVEK, G. Köppen's climate classification map for Brazil. Meteorologische Zeitschrift, v.22, n.6, p.711-728, 2013.

BRANDALISE, L. A. Programa Levantamentos Geológicos Básicos do Brasil. Folha Ponte Nova, SF.23-X-B-II. Minas Gerais: CPRM, 1991. 161p.

PORTAL G1. Cidades mineiras sofrem com inundações e deslizamentos de terra após fortes chuvas. Portal G1 MG, Belo Horizonte, 26 de novembro de 2021. Disponível em: <https://g1.globo.com/mg/minas-gerais/noticia/cidades-mineirassofrem-com-inundacoes-e-deslizamentos-de-terra-apos-fortes-chuvas.ghtml>

CODEMIG; CPRM. Portal de Geologia. 2014. Disponível em: $<$ http://www.portalgeologia.com.br/index.php/mapa/>.

CREPANI, E.; MEDEIROS, J. D.; HERNANDEZ FILHO, P.; FLORENZANO, T. G.; DUARTE, V.; BARBOSA, C. C. F. Sensoriamento remoto e geoprocessamento aplicados ao zoneamento ecológico-econômico e ao ordenamento territorial. São José dos Campos, INPE, 101 p., 2001.

GUIMARÃES, F. S.; CORDEIRO, C. M.; BUENO, G. T.; CARVALHO, V. L. M.; NERO, M. A. Uma proposta para automatização do índice de dissecação do relevo. Revista Brasileira de Geomorfologia, v. 18, n. 1, p. 155-167, 2017.

EMBRAPA. Sistema brasileiro de classificação de solos. 2 ed. Brasília: EMBRAPASPI, 2006, p.208.

FELIPPE, M. F.; JUNIOR, A. P. M.; MENDES, L. C.; CARNEIRO, P. S.; GONTIJO, B. M. Conexões geo-históricas e contemporâneas entre ocupação territorial, 
degradação ambiental e rarefação hídrica na Bacia do Rio Doce. Revista Geografias, edição especial, p.203-222, 2016.

GUERRA, A. J. T.; CUNHA, S. B. Degradação ambiental. In: GUERRA, A. J. T.; CUNHA, S. B.; Geomorfologia e meio ambiente. Rio de Janeiro: Bertrand Brasil, 2000, cap.7, p. 337-379.

IBGE. Cidades: Santa Cruz do Escalvado. Acesso em 21/10/2021. Disponível em: < https://cidades.ibge.gov.br/brasil/mg/santa-cruz-do-escalvado/panorama>

KÖPPEN, W. Das geographische System der Klimate. KÖPPEN, W. GEIGER, R. (Eds.). Handbuch der Klimatologie. Gebrüder Bornträger, Berlin, 1, 1936. p.1-44, part C.

LANDIS, J. R.; KOCH, G. G. The Measurement of Observer Agreement for Categorical Data. Biometrics, v. 33, n. 1, p. 159, mar. 1977.

LEÃO, M. R.; REZENDE, É. A.; SALGADO, A. A. R.; JÚNIOR, H. A. N. Erosão, denudação e evolução do relevo da média serra do espinhaço meridional, Minas Gerais. Revista Brasileira de Geomorfologia, v. 13, n. 2, p. 113-124, 2012.

LEMOS FILHO, L. C. A; FERREIRA, L. L. N.; LYRA, D. L. Variabilidade espacial de atributos do solo indicadores de degradação ambiental em microbacia hidrográfica. Revista agro@mbiente on-line, v. 11, n. 1, p. 11-20, 2017.

MARCOS, A. S. X. Mapeamento de fragilidade ambiental da bacia do Ribeirão do Escalvado-MG. 59f. Trabalho de Conclusão de Curso (Bacharelado em Geografia). Instituto de Ciências da Natureza, Departamento de Geografia, Universidade Federal de Alfenas, 2021.

PEREIRA, L. O.; SILVA, A. E. P.; NEGRI, R. G.; SANT'ANNA, S. J. S.; DUTRA, L. V.; FREITAS, C. C.; ERTHAL, G. J. Análise comparativa dos métodos de classificação SVM e Maxver-ICM Polarimétrico em imagem de radar ALOS PALSAR. In: XV Simpósio Brasileiro de Sensoriamento Remoto. Curitiba, 2011. Anais... São José dos Campos: INPE, 2011. p. 8223-8230.

RIBEIRO, R. J. C.; BAPTISTA, G. M. M.; BIAS, E. S. Comparação dos métodos de classificação supervisionada de imagem Máxima Verossimilhança e Redes Neurais em ambiente urbano. In: XIII Simpósio Brasileiro de Sensoriamento Remoto. Florianópolis, 2007. Anais... São José dos Campos: INPE, 2007. p. 5471-5478.

RODRIGUES, T. R. I.; ROCHA, A. M.; PEREZ FILHO, A. Mapeamento de uso e ocupação das terras na Bacia do Baixo Curso do Rio São José do Dourados-SP por sistemas de informações geográficas e imagem de satélite. In: XIII Simpósio 
Brasileiro de Sensoriamento Remoto. Florianópolis, 2007. Anais... São José dos Campos: INPE, 2007. p. 6091-6097.

ROSS, J. L. S. Análise empírica da fragilidade dos ambientes naturais antropizados. Revista do Departamento de Geografia, v.8, p. 63-74, 1994.

ROSS, J. L. S. Landforms and environmental planning: Potentialities and Fragilities. Revista do Departamento de Geografia, volume especial RGD 30 anos, p.38-51, 2012.

SOUZA, E.; TOLEDO, C. C.; FERNANDES FILHO, E. I. Uso do solo na Zona da Mata, Minas Gerais. In: SIMPÓSIO BRASILEIRO DE GEOGRAFIA FÍSICA APLICADA, 13., 2009. Anais..., Viçosa - MG: UFV, 2009.

USGS. Earth Explorer. Disponível em:<https://earthexplorer.usgs.gov/>. 